\title{
MANAGEMENT OF SPRINKLER IRRIGATION SYSTEM FOR CUMIN IN OLD VALLEY
}

\author{
BONDOK, M.Y. and AMAL F. EL-SHARKAWY
}

Agirc. Eng. Res. Instit. ARC,Dokki, Giza, Egypt.

(Manuscript received 28 September 2014)

\begin{abstract}
This investigation was carried out at private farm in $\mathrm{El}$ Gharbeia Governorate during seasons 2009 /2010 and 2010 /2011 to study the effects of two irrigation systems (surface and sprinkler) under three irrigation levels of $0.6,0.8$ and 1.0 from the ETc on applied irrigation water, yield and yield components for cumin. Data show the values of Kc during different stages .Kc increased from initial stage to mid-season then decreased to harvest stage Water applied values were $28,48,68,40$, and 20 $\mathrm{mm}$ for initial, development, mid-season, late and harvest stages respectively. Data indicated that, using sprinkler irrigation system reduced the applied of amounts of irrigation water by 47.85 and $45.50 \%$ in the two growing seasons comparing with surface irrigation. Meanwhile, yield increased by about 10.16 and $12.52 \%$ under sprinkler system irrigation comparing with surface irrigation in first and second growing seasons respectively . While decrease water use efficiency under surface irrigation by 52.7 and $53.6 \%$ comparing with sprinkler irrigation in two seasons respectively. On the other hand as water as decreased from 1.0 to 0.8 and 0.6 from ETc (evapotranspiration), Cumin yield decreased by 14.05 and 14.25 and by 25.6 and $26.89 \%$ in the two seasons respectively . Also, water use efficiency increased by $5.26,19.30$ , 10.17 and $16.9 \%$ in two seasons comparing by 1.0 ETC respectively .
\end{abstract}

Keywords : cumin, sprinkler irrigation, crop evapotranpriation

\section{INTRODUCTION}

Cumin is a cash crop with a short growing cycle. which demands little moisture and nutrient inputs. Generally cumin crop takes about $110-120$ days. The amount of irrigation water applied to the field are determined by how are irrigation systems and scheduling managed. Greater amounts are applied with surface irrigation more than with sprinkler irrigation system. The irrigation system delivers and distributes the water, but the produced crops consume the amount of needed water . Growers invest in better irrigation systems that enable more uniform water application and improve management of the amount applied.

Awady et al. (2003), working on pup-up sprinklers used in turf grass, studied water distribution uniformity in individual and grouping tests. Water was 
collected using catch cans for individual sprinkler heads of different types in $x-y$ and radial directions. Results taken in $x-y$ direction were fitted against those from radial. They also correlated between distribution uniformity determined from data in $x-y$ directions against those collected along laterals in triangular sprinkler heads layout . A high correlation among results was found. They also found how grass growth was affected by non- uniformity of irrigation application by sprinkler system.

Keller and Bliesner (1990) stated that most sprinkler irrigation systems require a minimum value of water distribution uniformity \{Christiansen, $s$ coefficient of uniformity $\mathrm{CU}>80 \%$. Low values of $\mathrm{CU}$ are usually indicators of a faulty combination of the number and size of nozzles, working pressure and spacing of sprinklers.

Tarjuelo et al. (1999) stated that the process of water application in SolidSet sprinkler systems mainly depends on the following factors:1- sprinkler water distribution pattern, the sprinkler design, the number and type of nozzles and the working pressure.

2- sprinkler layout, which refers to the spacing between sprinklers and 3- wind speed and direction.

Merriam and Keller (1978) stated that the procedure to determine sprinkler water distribution can be grouped into two types:1- apply the catch can grid to the existing irrigation system, evaluation of the system and 2- place a catch can grid around a single

Bondok and El-Sharkawy (2008) condacted experimental work during 2007 to study and to evaluate sprinkler irrigation system in order to improve efficiencies and management of system on cotton crop. The experimental work and data collecting on irrigation practice and operational condition were carried out in Gemmeza Research Station Gharbia Governorate. The results reveal that by using Bondok computer program in evaluating sprinkler system. Increased both average low quarter $21.5 \%$, individual sprinkler discharge $11.11 \%$, Distribution Uniformity (DU) $\%$ , Coefficient of Uniformity (CU) \%, Potential Application Efficiency of Low Quarter (PELQ) \% and Application Efficiency (AE) \% by 22.1, 9.1, 8.9, 9.5 respectively. Nevertheless Efficiency Reduction (ER) decreased by $21.0 \%$. Due to use, of sprinkler irrigation system, the yield decreased by $10.2 \%$. Nevertheless, due to sprinkler irrigation system use the water use efficiency increased by $75 \%$. The data show that by using sprinkler irrigation system, the amount of water saved increased by $50.9 \%$. While Arnaout (1995) stated that the efficiency of any irrigation system depends on water supply in the desired time. The average irrigation efficiency of the drip irrigation system increased by about 15.87 and $38.37 \%$ more than irrigation efficiency of sprinkler and furrow systems respectively. EL-Yazal et al. (1998) indicated that sprinkler irrigation system saved $17.81 \%$ of water applied and increased the yield by 
$22.6 \%$ compared to surface irrigation. The water utilization efficiency increased by $51 \%$ in sprinkler compared to surface irrigation system.. El-Gindy and Abdel-Aziz (2003) studied the effects of irrigation method ( drip and sprinkler) rate ( 50,75 , and $100 \%$ water consumptive use ) and interval (irrigation daily and irrigation at three-day intervals ) on maize water use efficiency and yield. They found that higher grain yields were obtained with drip irrigation than with sprinkler irrigation . Irrigation daily gave higher yields than irrigation at three-day intervals .

Joseph (1995) stated that crop response to water is a continuous function. In practice, there is no clear cut demarcation indicating when water requirement ends and leaching begins. The leaching requirement (LR) relates to an amount of water applied above the consumptive use requirement (CR) of a crop in order to facilitate the removal of accumulated salts. It is generally difficult to avoid deep percolation under normal field irrigation.

The objectives of this study were to management and evaluation of the sprinkler irrigation system for Cumin under different levels from ETc on irrigation water, yield and water use efficiency.

\section{MATERIALS AND METHODS}

An experiment was conducted to determine the effect of some irrigation systems as traditional and sprinkler irrigation, and irrigation level treatments as 0.6 ETc , 0.8 Etc and 1.0 ETc (ETc is crop evapotranspiration). The field experiments were performed at private farm in El Gharbeia Governorate during 2009/2010 and $2010 / 2011$ seasons. All treatments were randomized in three replicates . Physical andl mechanical analyses of the soil were determined according to Black (1965) in Table (1) Chemical analysis of irrigation water experimental field presented in table 12

Table 1. Mechanical analysis and some soil moisture contents of the studied soil experimental.

\begin{tabular}{|c|c|c|c|c|c|c|c|}
\hline Depth $\mathrm{cm}$ & $\begin{array}{c}\text { Fine } \\
\text { sand\% }\end{array}$ & $\begin{array}{c}\text { Coarse } \\
\text { sand\% }\end{array}$ & Silt\% & Clay\% & $\begin{array}{c}\text { Soil } \\
\text { texture }\end{array}$ & FC.\% & W.P.\% \\
\hline $0-20$ & 3.00 & 20.70 & 27.00 & 49.30 & Clay & 42.10 & 21.30 \\
\hline $20-40$ & 3.85 & 20.65 & 27.10 & 48.40 & Clay & 42.60 & 20.50 \\
\hline $40-60$ & 3.95 & 20.40 & 28.20 & 47.45 & Clay & 43.70 & 21.90 \\
\hline $60-80$ & 4.45 & 20.45 & 28.20 & 46.90 & Clay & 44.40 & 22.50 \\
\hline
\end{tabular}


Table 2. Chemical analysis values of irrigation water experimental filed.

\begin{tabular}{|c|c|c|c|c|c|c|c|c|c|}
\hline \multirow{2}{*}{ ECdS/m } & \multicolumn{4}{|c|}{ Soluble cations,meq/I } & \multicolumn{4}{c|}{ Soluble anions,meq/l } & \multirow{2}{*}{ SAR } \\
\cline { 2 - 11 } & $\mathrm{Ca}$ & $\mathrm{Mg}$ & $\mathrm{Na}$ & $\mathrm{K}$ & $\mathrm{Co} \mathrm{3}$ & $\mathrm{Hco} 3$ & $\mathrm{~S} 04$ & $\mathrm{Cl}$ & \\
\hline 1.34 & 5.44 & 6.53 & 5.9 & 0.1 & 0.85 & 3.9 & 6.0 & 7.9 & 2.8 \\
\hline
\end{tabular}

Average ETo calculated according to the data recorded by Kator weather station , El Gharbeia Governorate which is affiliated to the Central Laboratory for Agricultural Climate ,Ministry of Agriculture and Land Reclamation .

Table 3. ETo $\mathrm{mm} /$ day for the location of Kator

\begin{tabular}{|l|l|l|l|l|l|}
\hline Month & Nof & Des & Jan & Fe & Mar \\
\hline Eto & 2.75 & 2 & 1.8 & 2.1 & 3.25 \\
\hline
\end{tabular}

Seeds of Cumin were sown on Nov. 15 and 20 at $1^{\text {st }}$ and $2^{\text {nd }}$ seasons, respectively, in hills, $25 \mathrm{~cm}$. apart within rows $60 \mathrm{~cm}$ in between. All of the recommended agronomic practices were followed for cumin production in the region . Harvesting was on March for two seasons.

\section{Traditional irrigation:}

The irrigation water was supplied to the border surface irrigation through a circular orifice of $10 \mathrm{~cm}$ diameter and its discharge rate was measured by using the equation of James (1988) as follows :

$$
\mathrm{Q}=0.61 \mathrm{KAH}^{1 / 2}
$$

Where,

$\mathrm{Q}=$ orifice discharge, $1 / \mathrm{s}$

$A=$ the area of orifice opening, $\mathrm{cm}^{2}$

$\mathrm{H}=$ head, $\mathrm{m}$

$\mathrm{K}=$ unit constant. $\left(\mathrm{K}=0.443\right.$ for $\mathrm{Q}$ in $\mathrm{l} / \mathrm{s}, \mathrm{A}$ in $\mathrm{cm}^{2}$, and $\mathrm{H}$ in $\left.\mathrm{m}\right)$

\section{Sprinkler system}

The system had portable mainlines, sub mains, laterals, portable pumping plant, Single nozzle sprinkler $3 \mathrm{~mm}$ in diameter and $0.6 \mathrm{~m}^{3} / \mathrm{h}$ discharge made by (NAN). Fig .1 shows layout of sprinkler irrigation system. Fig. 2 shows evaluation of sprinkler irrigation system. 


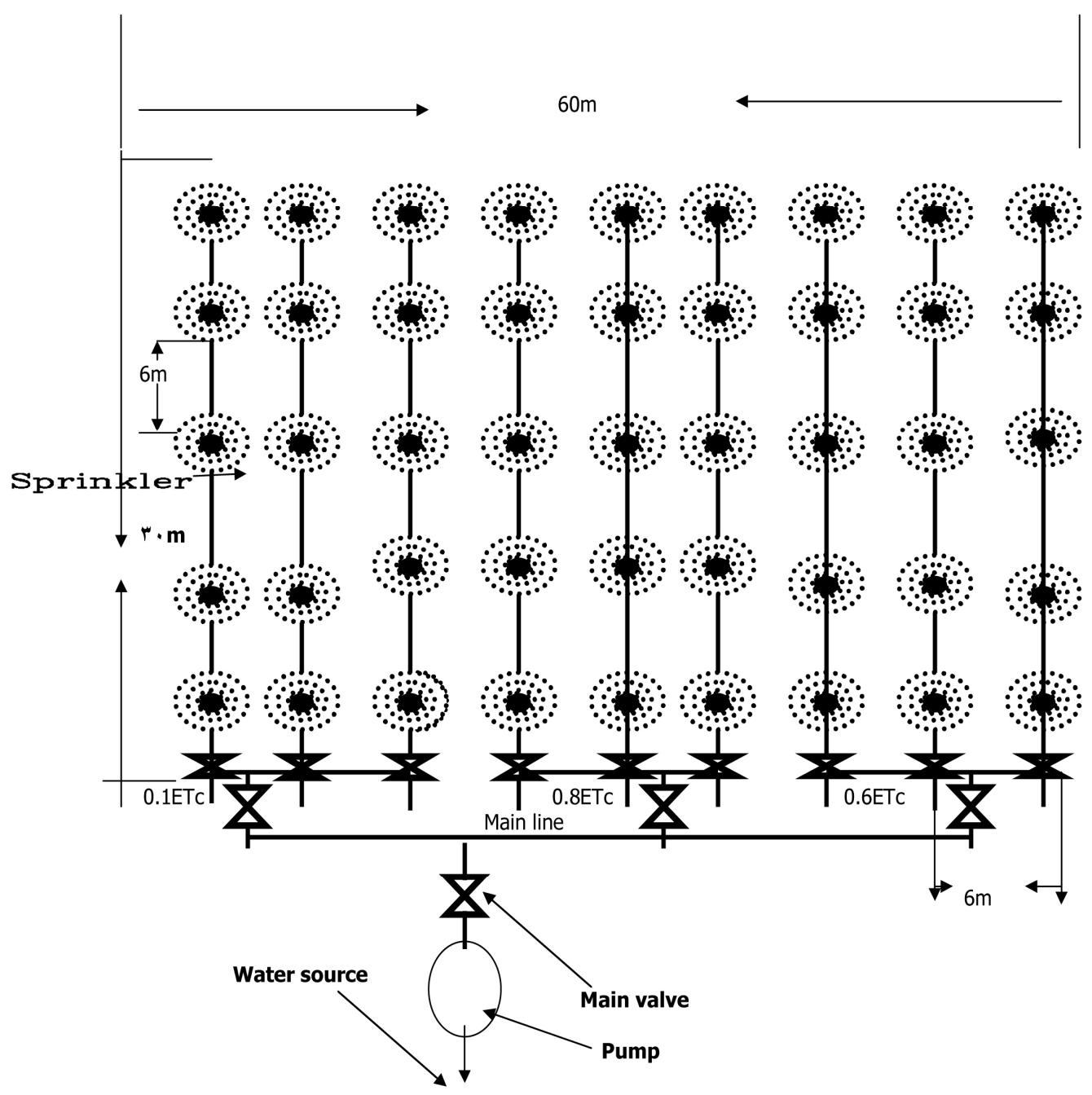

Fig. 1. layout of sprinkler irrigation system. 


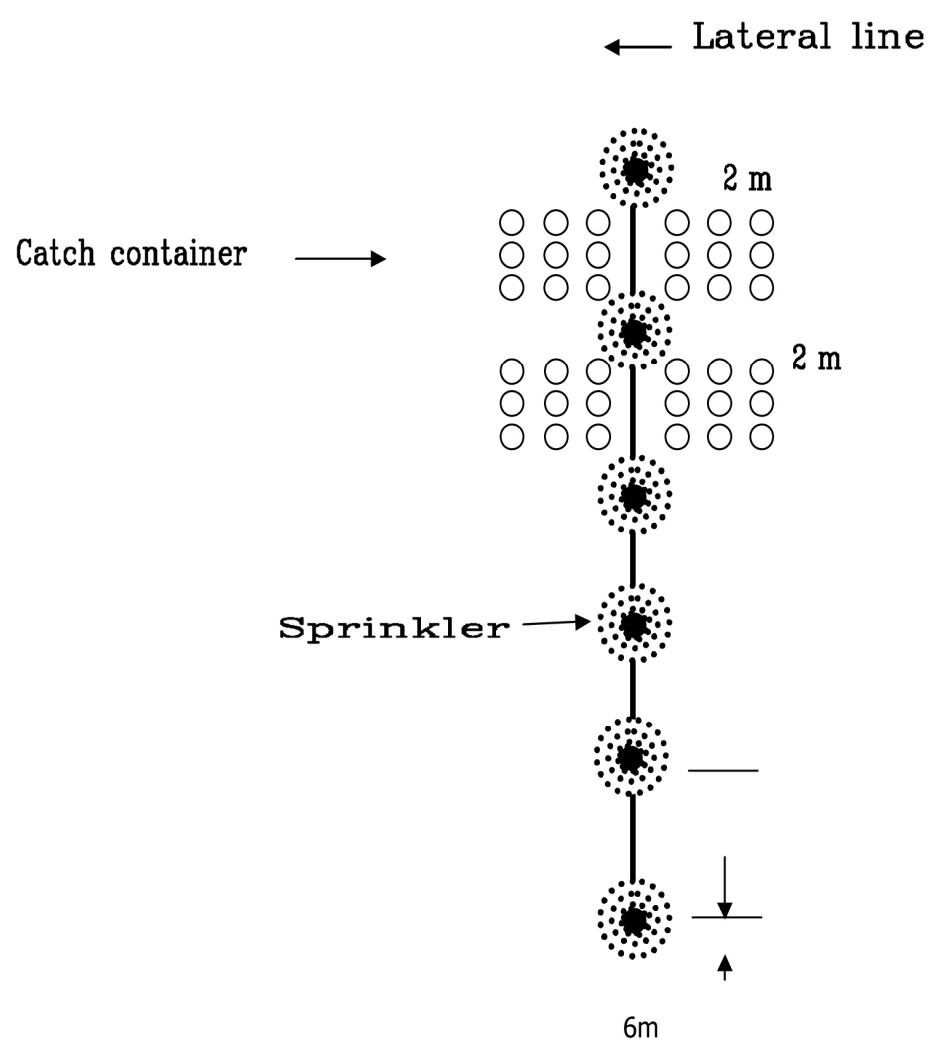

Fig. 2. Evaluation of sprinkler irrigation system.

\section{Equipment:}

1) Pressure gauge: (0-6) bar with pitot attachment.

2) Stopwatch: with an accuracy of 0.01 second was used to determined different times of the experiments.

3) Large container: of known volume clearly marked.

4) 2 -m length of flexible hose having diameter appreciably larger than the outside diameter of nozzles.

5) sixty catch cans .

6) 500-ml graduated cylinder to measure volume of catching water in cans.

\section{Measurements:}

1) Spacing between sprinklers along lateral line.

2) Spacing between lateral lines along the main line.

3) Measuring depths of water caught in catch cans.

4) Duration of the test.

5) Water pressure at the sprinkler nozzles.

6) Rate of flow from the tested sprinklers. 


\section{Calculation:}

Irrigation uniformity and efficiencies for the system were calculated according to Merriam and keller (1978) (using bondok computer program. 2006)

\section{Leaching requirement}

Leaching requirement (LR) is the minimum amount of irrigation water supplied that must be drained through the root zone to control soil salinity at the given specific level. The leaching requirement was estimated according to Doorenbos and Pruitt, (1977) for surface irrigation methods by the following equation.

$$
\text { ECW }
$$

$\mathrm{LR}=\mathbf{- 1} \mathrm{ECe}-\mathrm{Ecw}$

where:

$\mathrm{ECW}=$ electrical conductivity of irrigation water, $\mathrm{dS} / \mathrm{m}$.

$\mathrm{ECe}=$ electrical conductivity of the soil saturation extract $\mathrm{dS} / \mathrm{m}$.

\section{Moisture content:}

Water holding capacity (W.H.C) $\mathrm{mm}$ :

W.H.C $=(\mathrm{FC} \%-$ PWP \% $) \times$ bulk density, ${\mathrm{g} . \mathrm{cm}^{-3}}^{-} \times$root zone, $\mathrm{cm} \times 10$

Where:

FC is field capacity.

PWP is permanent wilting point.

Maximum net water requirement (Max - n.w .r ) mm.

Max. $n . w . r=M A D \times$ W.H.C $\div 100$

MAD management allowable deficit $\mathrm{mm} / \mathrm{m}$

Maximum gross water requirement ( $m a x$. g.w.r ) mm

Max.g.w.r. $=\max . n . w . r . ~ \times 100 \div \mathrm{AE}$

AE : Application efficiency, \%

Irrigation interval II (day)

II $=$ max-n.w.r. $\div$ ETc

Time for irrigation , TIR ( $h$ )

TIR= Max-g.w.r. $\div$ infiltration rate, $\mathrm{mmh}^{-1}$

Infiltration rate of the soil were determined in the field using double ring ( cylinder infiltrometer )

\section{Crop coefficient}

$$
\text { Kc }=\text { Etc } / \text { ETo }
$$


where

$\mathrm{Kc}=$ is crop coefficient

ETc = actual crop evapotranspiration , $\mathrm{mm}$

$\mathrm{ETO}=$ Reference evapotranspiration , $\mathrm{mm}$

Yield:

Harvesting should be done, when plants are yellowish brown by cutting the whole plants and separate the seeds, and computed the yield $\mathrm{kg} /$ fed.

\section{Water Use Efficiency (WUE):}

WUE $=\{$ Average yield, $\mathrm{kg} /$ Fed $\} /\left\{\right.$ Applied water, $\mathrm{m}^{3} /$ fed $\}=\mathrm{kg} / \mathrm{m}^{3}$ (Michael,1978).

\section{RESULTS AND DISCUSSION}

\section{Crop coefficient (Kc)}

The factors affecting on the value of the crop coefficient Kc ( where $\mathrm{Kc}=\mathrm{Etc}$ /Eto ) are mainly the crop characteristics, sowing date ,rate of crop development , length of growing season. The average values of $\mathrm{Kc}$ for cumin in different stages is shown in .Fig. (3). The values increased from initial, development to mid-season then decreased in late and harvest stages. Initial stage Kc was 0.35 , at development stage was 0.75 , and mid-season stage was 1.0 , for the late season stage it was 0.7 and for the harvest stage it was 0.5 .The same trend was found in the second season where the values were $0.30,0.7,1.00,0.6$ and 0.45 for the initial ,development , mid season, late season and harvest stages respectively .

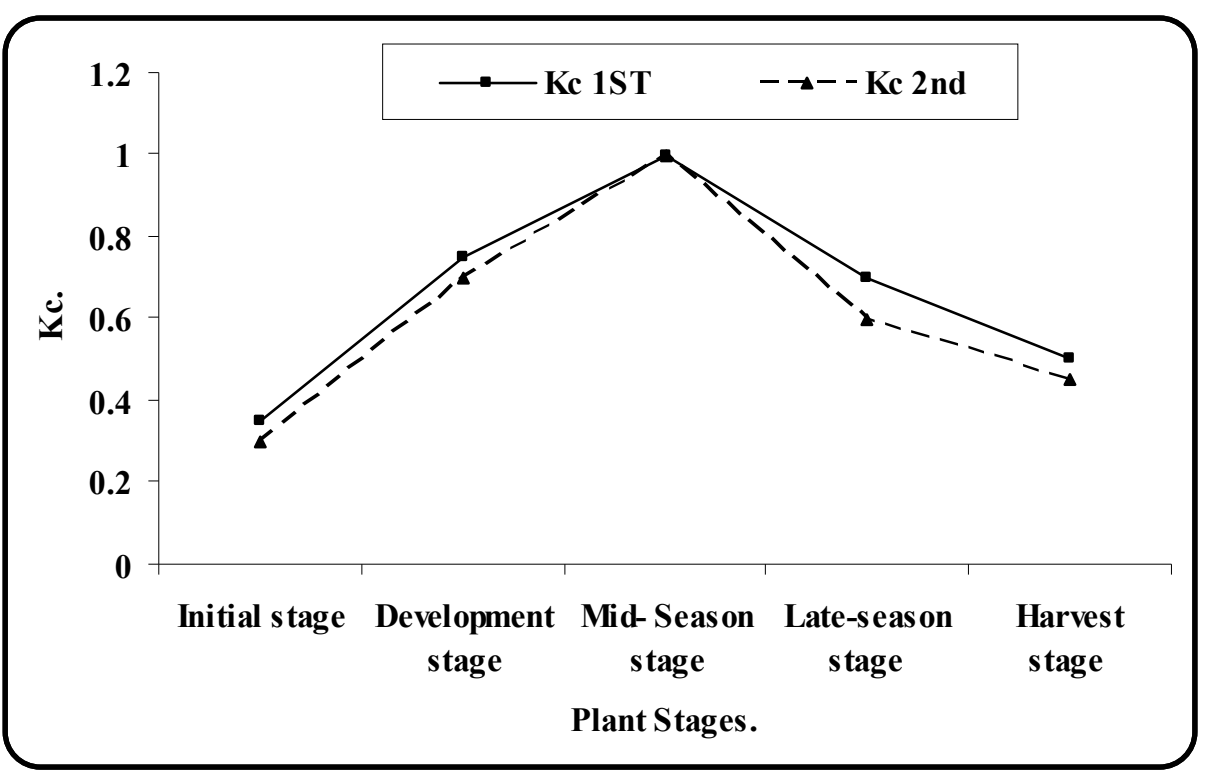

Fig. 3. Seasonal evaluation of Kc during cumin growth stages . 


\section{System Evaluation}

Data in Table (4) show the sprinkler irrigation system evaluation of distribution uniformity (DU) \%,coefficient of uniformity\% , average water application $(\mathrm{R}) \mathrm{mm} / \mathrm{h}$, potential application efficiency of low quarter (PELQ) \% ,application efficiency \%, system efficiency \%,system coefficient of uniformity(SCU) $\%$, system distribution uniformity (SDU), field water use efficiency ( $F W \cup E$ ) $\mathrm{kg} / \mathrm{m}^{3}$ .The values in Table (4) are 75,80 12.5, 78.4,2.66, $74,95,82,77$ and $70 \%$ for distribution uniformity (DU) \%,coefficient of uniformity\%, average of water application (R)mm/h, potential application efficiency of low quarter (PELQ) \% ,application efficiency $\%$, system efficiency \%,system coefficient uniformity(SCU) \% $\%$, and system distribution uniformity (SDU)respectively.

Table 4. Sprinkler irrigation efficiency.

\begin{tabular}{|l|l|c|}
\hline 1 & \multicolumn{1}{|c|}{ Site } & AL-Gharbeia \\
\hline 2 & Crop. & Cumin \\
\hline 3 & Distribution Uniformity (DU) \% & 75 \\
\hline 4 & Coefficient of uniformity (CU) \% & 80 \\
\hline 5 & Average rate of water application (R) mm/h. & 12.5 \\
\hline 6 & Potential application Efficiency of leastQuarter (PELQ) \% & 78.4 \\
\hline 7 & Efficiency Reduction (ER) \% & 2.66 \\
\hline 8 & System Potential Application Efficiency of least Quarter\% (SPELQ) & 74 \\
\hline 9 & Application efficiency (AE) \% & 95 \\
\hline 10 & System Efficiency (SE) \% & 82 \\
\hline 11 & System Coefficient Uniformity ( S CU) \%. & 77 \\
\hline 12 & System Distribution Uniformity ( S DU) \%. & 70 \\
\hline
\end{tabular}

\section{Water applied during different stages under sprinkler irrigation .}

Data in Table ( 5 ) show the average of water applied during different stages $\mathrm{mm} /$ period for cumin in two seasons. Water applied in the initial stage was 28 $\mathrm{mm}$ for 25 days, in the development stage was $48 \mathrm{~mm}$ for 30 day, in the mid season had the highest value of $68 \mathrm{~mm}$ for 30 days. Then water application decreased in late season to $40 \mathrm{~mm}$ for 20 days and in the harvest stage it was 20 for 10 days .

Data in Table (5) show the average water applied during different stages in two seasons (initial, development ,mid, late and harvest )under sprinkler irrigation .Water applied increased from initial to development stages and the maximum water applied was in mid season then decreased in late and harvest stages under all levels of irrigation. The highest values in all stages under 1.0 ET, were 117.6, 201.6 , 285.6 , 
168.0 and $84 \mathrm{~m}^{3} /$ Fed recp. . Under $0.8 \mathrm{ETc}$, the values decreased to $94.00,161.28$ , 228.48, 134.4and $67,2 \mathrm{~m}^{3} /$ fed...Meanwhile the lowest values under 0.6 ETc. were $70.56120 .36,171.36,100.8$ and $50.4 \mathrm{~m}^{3} /$ fed.for initial, development, mid, late and harvest stages, respectively.

Table 5. Sprinkler irrigation depth for cumin crop during stages for growing season.

\begin{tabular}{|c|c|c|c|c|c|c|}
\hline Stages & Initial & Development & Mid-season & $\begin{array}{c}\text { Late } \\
\text { season }\end{array}$ & Harvest & Total \\
\hline day Period & 25 & 30 & 30 & 20 & 10 & 115 \\
\hline $\begin{array}{c}\text { Water applied } \\
\text { mm/Period }\end{array}$ & 28 & 48 & 68 & 40 & 20 & 204 \\
\hline L.R $\mathrm{m}^{3} / \mathrm{fed}$. & & & & & & 128.5 \\
\hline Rain $\mathrm{m}^{3} / \mathrm{fed}$. & 36 & & & 63 & & 72 \\
\hline $\begin{array}{c}\text { Water applied } \\
1.0 \mathrm{ETc} \\
\mathrm{m}^{3} / \mathrm{fed}\end{array}$ & 117.6 & 201.6 & 285.6 & 168 & 84 & 1057.3 \\
\hline $\begin{array}{c}\text { Water applied } \\
0.8 \mathrm{ETc} \\
\mathrm{m}^{3} / \mathrm{fed}\end{array}$ & 94.00 & 161.28 & 228.48 & 134.4 & 67.2 & 860.36 \\
\hline $\begin{array}{c}\text { Water applied } \\
0.6 \mathrm{ETc} \\
\mathrm{m}^{3} / \text { Fed. }\end{array}$ & 70.56 & 120.36 & 171.36 & 100.8 & 50.4 & 662.58 \\
\hline
\end{tabular}

\section{Irrigation water.}

Irrigation water for Cumin and saving under some different irrigation systems (Sprinkler and traditional irrigation systems) and sprinkler irrigation level treatments as $0.6,0.8$ and 1.0 of ETc was crop evapotranspiration

\section{Effect of irrigation systems}

Data in Table ( 6 ) indicate that the irrigation water applied for Cumin was reduced by 47.85 and $45.50 \%$ using sprinkler irrigation comparing with traditional irrigation in the first and second seasons. 
Table 6. The effect of surface and sprinkler irrigation systems on average cumin yield and water use efficiency.

\begin{tabular}{|c|c|c|c|c|}
\hline Seasons & Irrigation systems & $\begin{array}{c}\text { Average yield } \\
\mathrm{kg} / \mathrm{fed} .\end{array}$ & $\begin{array}{c}\text { Amount of water } \\
\mathrm{m}^{3} / \mathrm{fed} .\end{array}$ & $\begin{array}{c}\text { Water use efficiency } \\
\mathrm{kg} / \mathrm{m}^{3}\end{array}$ \\
\hline \multirow{2}{*}{$1^{\text {st }}$} & Sprinkler & 525 & 860.25 & 0.62 \\
\cline { 2 - 5 } & Surface irrigation. & 476.6 & 1650 & 0.29 \\
\hline \multirow{2}{*}{$2^{\text {nd }}$} & Sprinkler irrigation. & 520 & 820.24 & 0.65 \\
\cline { 2 - 5 } & Surface irrigation. & & 1505 & 0.30 \\
\hline
\end{tabular}

\section{Effect of sprinkler irrigation levels .}

Data in Table (7) show sprinkler irrigation levels for $0.6,0.8$ and 1.0 ETc. .We found that the amount of water decreased from 1057.8 to 860.36 and 662.58 $\mathrm{m}^{3} /$ fed.under $1.0,0.8$ and 0.6 ETc. respectively. The same trend in the second season. The values were $1007.3,820.24$ and $633.18 \mathrm{~m}^{3} /$ fed.respectively .

Table 7. The effect of sprinkler irrigation levels on average cumin yield and water use efficiency.

\begin{tabular}{|c|c|c|c|c|c|}
\hline Seasons & $\begin{array}{l}\text { Irrigation } \\
\text { system }\end{array}$ & $\begin{array}{l}\text { Irrigation } \\
\text { treatments }\end{array}$ & $\begin{array}{c}\text { Average yield } \\
\text { kg/fed. }\end{array}$ & $\begin{array}{l}\text { Amount } \\
\text { ofwater } \\
\mathrm{m}^{3} / \mathrm{fed}\end{array}$ & $\begin{array}{c}\text { Wateruse } \\
\text { efficiency } \\
\mathrm{kg} / \mathrm{m}^{3}\end{array}$ \\
\hline \multirow[t]{3}{*}{$1^{\text {st }}$} & \multirow{3}{*}{$\begin{array}{c}\text { Sprinkler irr } \\
\text { igation. }\end{array}$} & $1.0 \mathrm{Etc}$ & 605 & 1057.8 & 0.57 \\
\hline & & $0.8 \mathrm{Etc}$ & 520 & 860.36 & 0.60 \\
\hline & & $0.6 \mathrm{Etc}$ & 450 & 662.58 & 0.68 \\
\hline \multirow[t]{3}{*}{$2^{\text {nd }}$} & \multirow{3}{*}{$\begin{array}{l}\text { Sprinkler } \\
\text { irrigation. }\end{array}$} & $1.0 \mathrm{Etc}$ & 595 & 1007.3 & 0.59 \\
\hline & & $0.8 \mathrm{Etc}$ & 530 & 820.24 & 0.65 \\
\hline & & $0.6 \mathrm{Etc}$ & 435 & 633.18 & 0.69 \\
\hline
\end{tabular}

\section{Yield}

\section{Effect of irrigation systems}

Fig.4 shows the effect of some irrigation systems on cumin yield .Yield increased by 10.16 and $12.52 \%$ under sprinkler system irrigation comparing by traditional irrigation in the first and second seasons . 


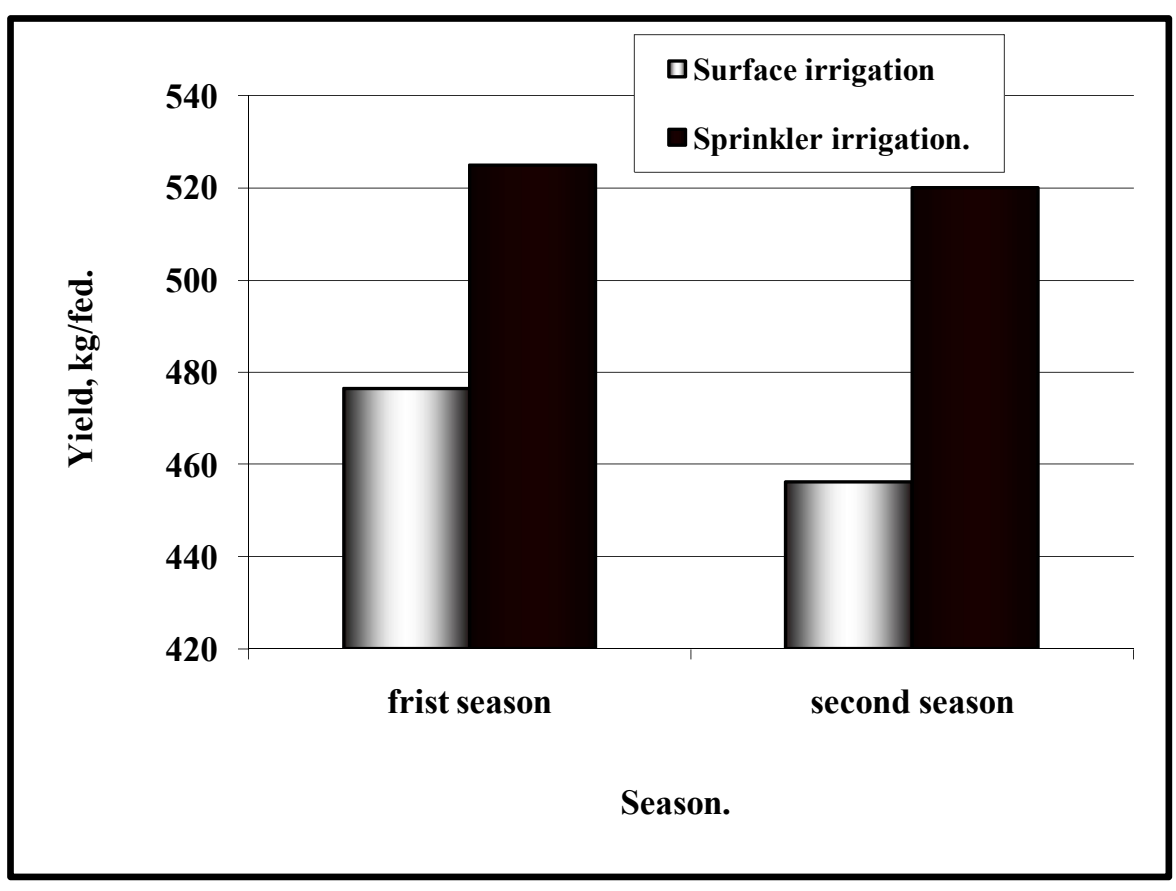

Fig. 4 . Effect of irrigation system on cumin yield .

\section{Sprinkler irrigation levels.}

Fig. 5 shows that the relation between yield and water deficit is inverse. Cumin yield decreased in linear relationship as water deficit increased under sprinkler system .Data show that, yield decrease by 14.05 and $25.6 \%$ under irrigations with 0.8 and 0.6 ETc compared by 1.0 ETc. In second the season, the ratios of decrease were 14.29 and $26.89 \%$ under 0.8 and 0.6 ET compared by 1.0 ETc .

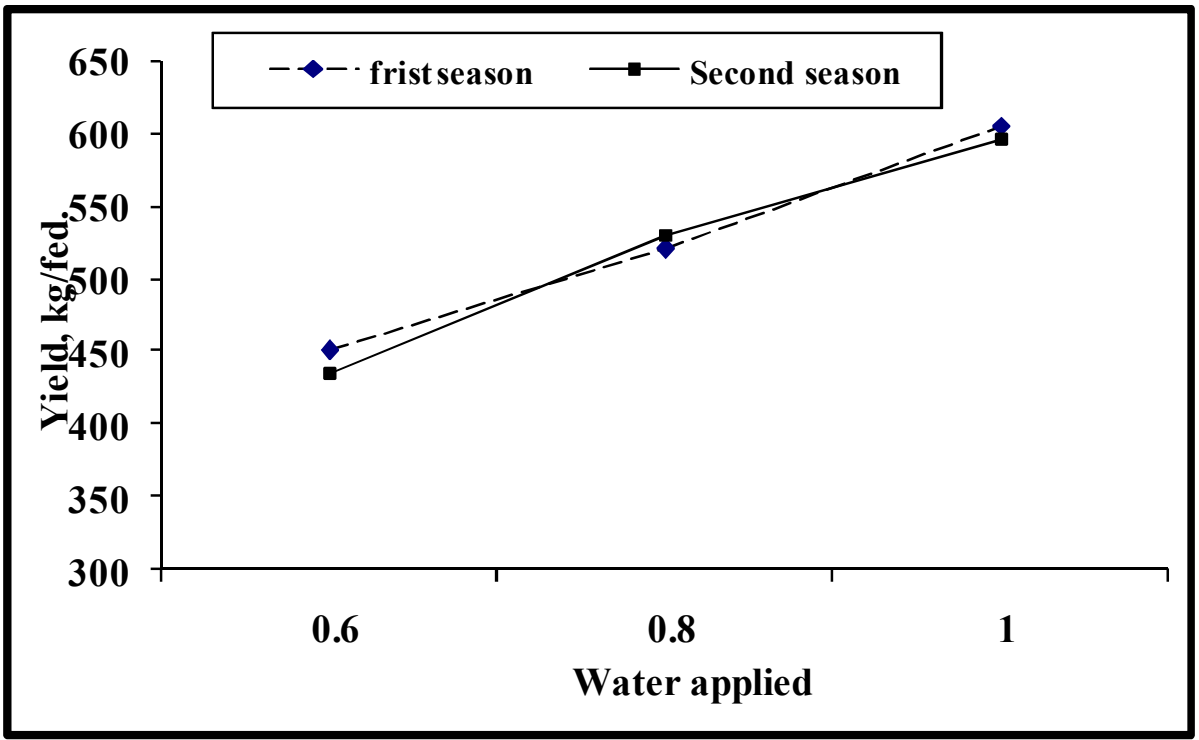

Fig. 5. Effect of water deficit on cumin yield . 


\section{Water use efficiency (W U E) Irrigation system}

Fig. 6 shows decreased water use efficiency under traditional irrigation by $52.7 \%$ compared by sprinkler irrigation The same trend was noticed in second season decrease with $53.6 \%$.

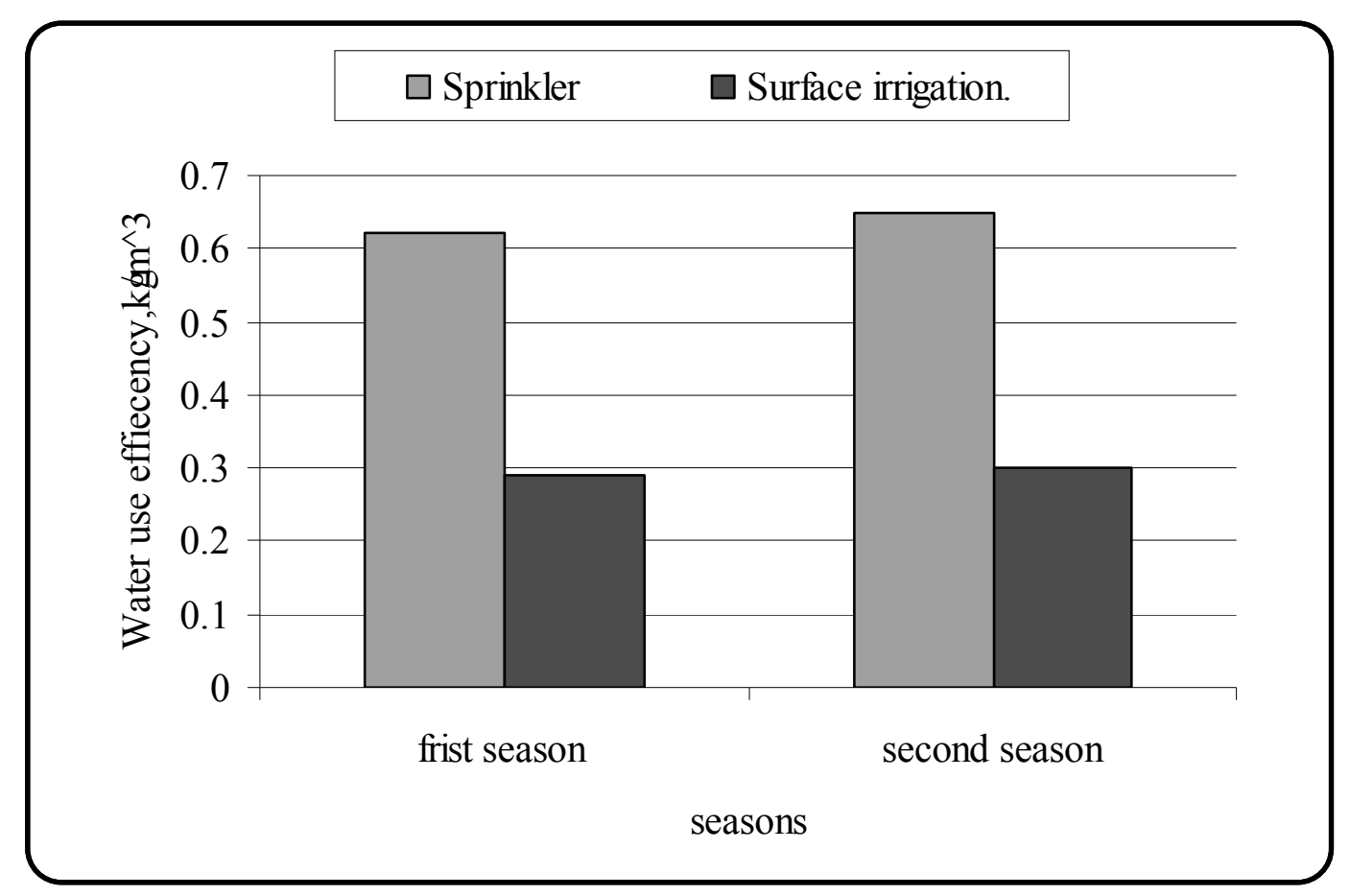

Fig. 6 . Effect of irrigation system on water use efficiency for Cumin crop.

\section{Sprinkler irrigation level}

Fig. 7 . shows that , the highest value was by using level 0.6 ETc. It was 0.68 $\mathrm{kg} / \mathrm{m} 3$. The lowest value was $0.57 \mathrm{~kg} / \mathrm{m} 3$ by using $1.0 \mathrm{ETc}$ applied . The value was $0.60 \mathrm{~kg} / \mathrm{m} 3$ by using $0.8 \mathrm{ET}$ water. The second season data took the same trend by values of $0.59,0.65$ and $0.69 \mathrm{~kg} / \mathrm{m}^{3}$ by using $1.0,0.8$ and 0.6 ETc applied water respectively . 


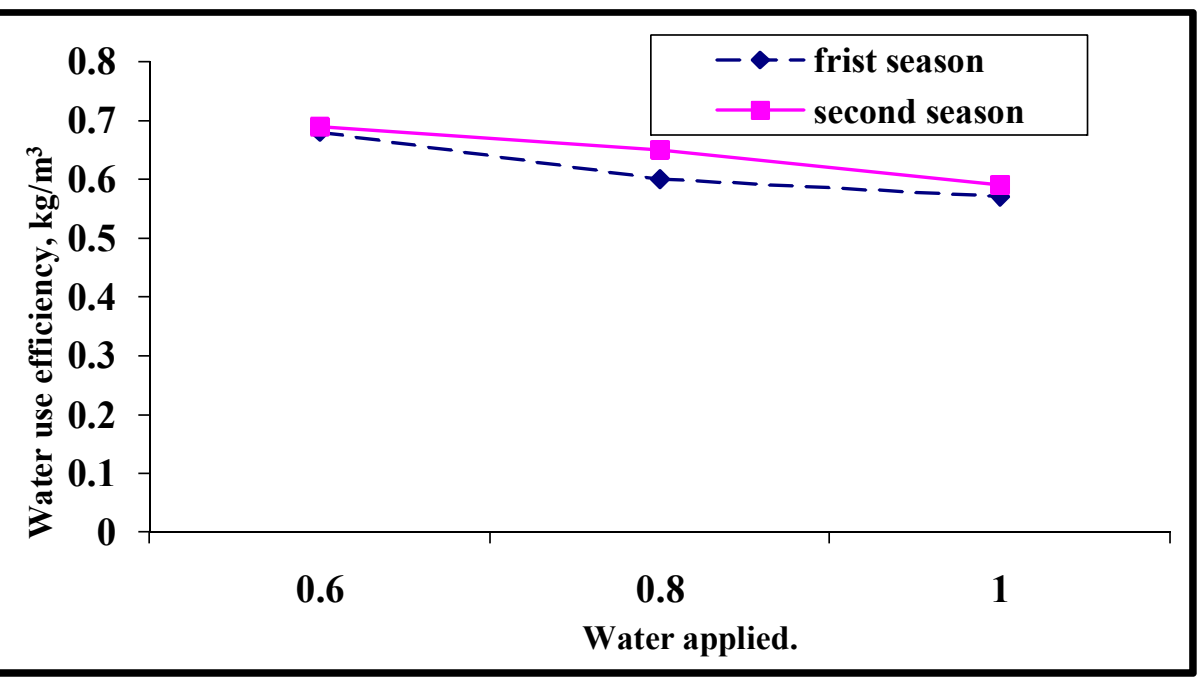

Fig. 7. Effect of water deficit on water use efficiency .

\section{Conclusion}

The main results in the present work can be summarized and concluded in the following points:

Effect of some irrigation systems

Saving in irrigation water by using sprinkler irrigation system was 47.85 and $45.50 \%$ in two seasons comparing with surface irrigation. Yield increased by 10.16 and $12.52 \%$ under sprinkler system irrigation comparing with surface irrigation in the first and second seasons. Water use efficiency under surface irrigation decreased by 52.7 and $53.6 \%$ respectively comparing with sprinkler irrigation in two seasons

Effect of irrigation levels.

Amount of irrigation water decreased from 1057.8 to 860,36 and 662.58during the first season. It decreased from 1007.3 to 820.24 and $663.17 \mathrm{~m}$ /fed. during the second season . Cumin yield decreased by 14.05, $25.6,14.29$ and $26.89 \%$ respectively under 0.8 and 0.6 ETc comparing by 1.0 ETc in the two seasons .

Water use efficiency increased by $5.26,19.30,10.17$ and $16.9 \%$ respectively in two seasons comparing with 1.0 ETc applied water . 


\section{REFERENCES}

1. Arnaout, M.A. 1995. A comparative study between some irrigations. Miser J. Agric. Eng, 12 (1), 46 - 54 .

2. Awady, M.N., A.M.El-Berry, M.T. El-Tantawy and E.M. Kamal. 2003. Evaluation of Growers Sprinkler Irrigation System Management in Bustan Area . The $11^{\text {th }}$ An. Conf. ,Misr. J. Ag. Eng. :195- 209.

3. Black, C. A. 1965. Method of soil and water analysis. Soc. Agron. Inc. Pub. , Madison Wisc. , U.S. A. No. 9 part 2.

4. Bondok, M. Y. 2006. Improving the efficiency and management of modern irrigation systems for some orchard crops using computer ph. D.,thesis Agric . Mech., AL-Mansoura Univ.

5. Bondok, M. Y. and A. F. El-Sharkawy. 2008. Management of sprinkler irrigation system for cotton in old valley. The $15^{\text {th }}$. Ann. Conf. Misr Soc. Ag. Eng. $12-$ 13 March , : $407-424$.

6. Doorenbos, J. and W. O. Pruitt. 1977. Guidline of predicting crop water requirements. Irr- and Drainage paper no. 24. F.A.O. 144 .

7. El-Gindy , A. M., and A. A. Abdel-Aziz. 2003. Maximizing water use efficiency of maize crop in sandy soil. Arab universities Journal of Agricultural Sciences 11 ( 1 ) : 439-452

8. EL-Yazal M.N. S., H. EL-Banna and S. EL-Kady. 1998. Cotton crop response to sprinkler irrigation system in Egyptian old land. Egypt. J. Agric .Res. 76 (3) . 1347 - 1361.

9. Keller J. and R. D. BLiesner. 1990. Sprinkler and trickle irrigation ., An avi Book Chapman \& Hall New York : 629 pp.

10. James, L.C. 1988. Principles of farm irrigation system design . John Wiley \&Sons New york Chichester Brisbane Toronto Singapore, 410p .

11. Joseph, S. 1995. Irrigation management and salinity control. Water Irrigation Review ,15 ( 3)

12. Michael, A. M. 1978. Irrigation theory and practice. Pp. 448- 584. Viskas Puplishing House PVTLTD: New Delhi.

13. Merriam, J. L. and J. Keller. 1978. Farm irrigation system evaluation. A guide for management, $3^{\text {rd. }}$ Utah State Univ., Logan,pp 285.

14. Tarjuelo, J. M, J. Montero , M. valiente, F. T. Honrubia and J. Ortiz. 1999. Irrigation uniformity with medium size sprinkler part 1: Characterization of water distribution in no-wind conditions. Am. Soc. Agr. Eng. , (3), 665- 688. 


\section{إدارة الري بالرش على محصول الكمون فى الوادى القليم}

\section{محمد يسرى بندق و أمال فتوح الثرقاوى}

$$
\text { - معهد بحوث الهندسة الزراعية - مركز البحوث الزراعية - دقي - مصر • }
$$

اجريت هذه التجربة بمحافظة الغربية لدر اسة ناثير نظام الرى بالرش تحت معدلات مختلفة

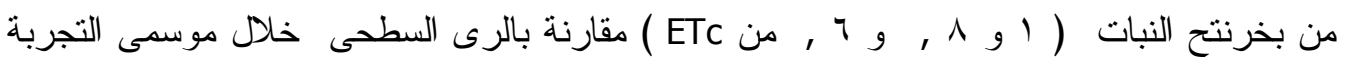

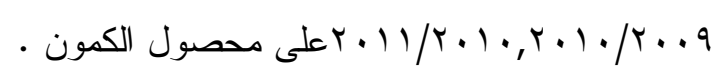
وكانت أهم النتائج كالتالى :

اختلفت قيم معامل المحصول باختلاف مر احل النمو حيث زادت من مراحل النمو الاولى الى الى

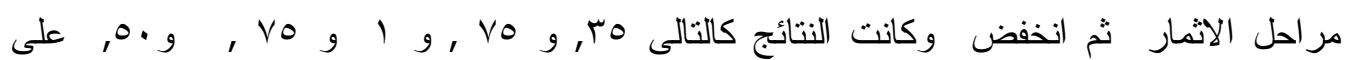
التو الى.

تتأثز الاحتياجات المائيه للنبات باختلاف مراحل النمو،حيث كان متوسط عمق المياه

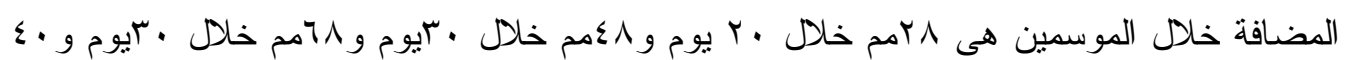

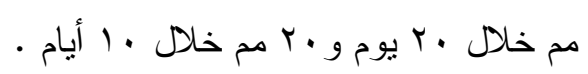

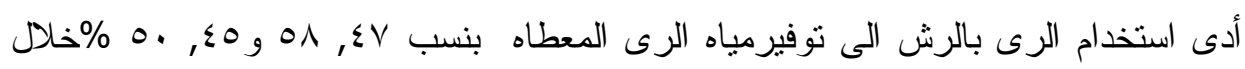

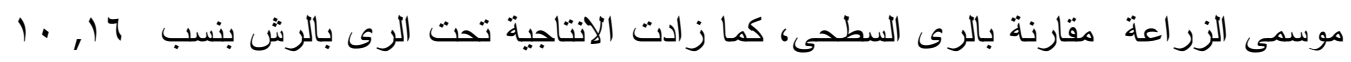

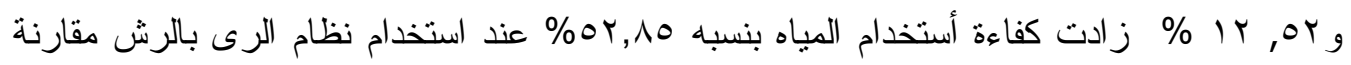

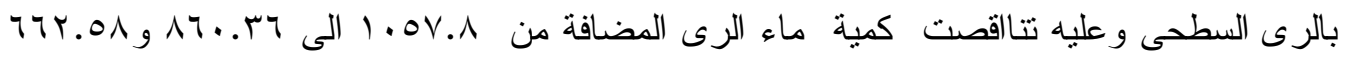

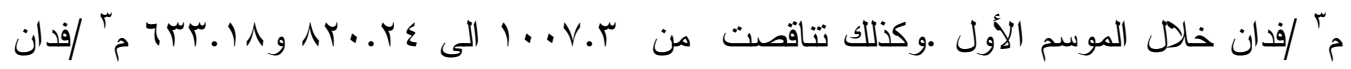

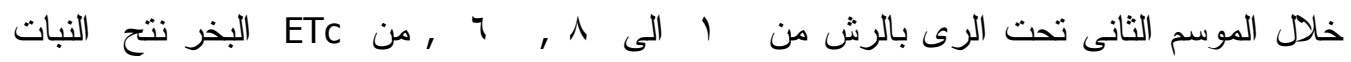

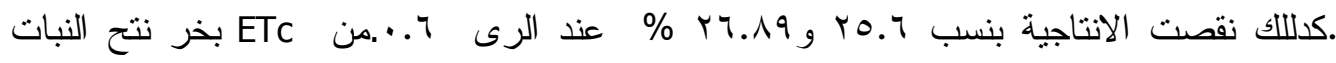

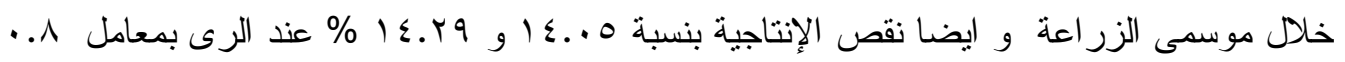

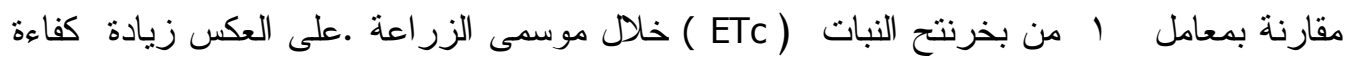

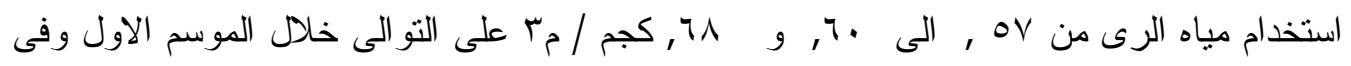

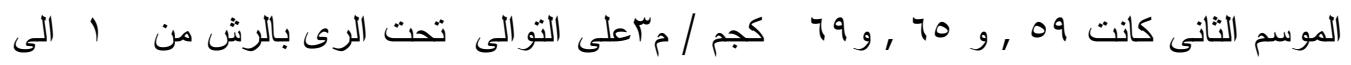

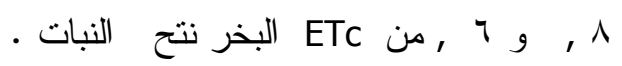
نوصى تحت ظروف محافظة الغربية للحصول على اعلى انتاجية و توفيرمياه الرى

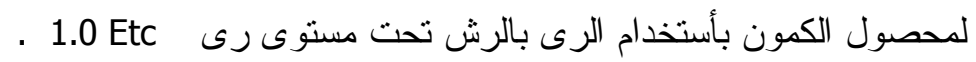

